\title{
Unemployment and Organizational Commitment: Evidence from a Panel of Australian Manufacturing Firms
}

\author{
NICHOLAS APERGIS \\ University of Piraeus*
}

Higher unemployment increases the cost of job loss and heightens employees' feelings of job insecurity. The paper argues that these two effects could have a positive influence on employee organizational commitment. Using data from the Household, Income and Labor Dynamics in Australia (HILDA) microdata database, we find that employees in high unemployment regions are more committed to their organization, while the effect of unemployment on employee's commitment is stronger in the private sector.

Keywords: Unemployment, Loyalty, Australia

JEL Classifications: E23; J28; C33

\section{Introduction}

Organizational commitment and its link to productivity and organizational performance have been widely researched in the extant literature. Organizational commitment has been associated with superior employee job performance (Meyer et al., 2002), high customer satisfaction (Dale and Fox, 2008) and lower turnover and absenteeism (Allen and Meyer, 1996). Committed employees interact with colleagues to improve working relations and they play an active role in promoting organizational goals (Kleine and Weißenberger, 2014). Many studies have also used organizational commitment as an indicator of leadership effectiveness and researchers have made considerable efforts to identify its main antecedents (Podsakoff et al., 1996; Walumbwa and Lawler, 2003; Dale and Fox, 2008; Fulmer and Gelfand, 2012).

The bulk of the literature on the antecedents of commitment has focused on job demands, i.e. job characteristics that require employees' physical and psychological efforts, and on

\footnotetext{
* The author expresses his special gratitude to three referees of this journal for their suggestions and comments that improved the merit of this work. Special thanks also go to both the Editor and to the Guest Editor for giving him the chance to revise his work. Needless to say, the usual disclaimer applies. Author's e-mail: napergis@unipi.gr

(C) 2016 Nicholas Apergis. Licensed under the Creative Commons Attribution - Noncommercial 3.0 Licence (http://creativecommons.org/licenses/by-nc/3.0/. Available at http: //rofea.org.
} 
characteristics that are valuable job resources, including supervisory support, career advancement, task variety, role clarity, and participation in decision making (Demerouti et al., 2001; Bakker et al., 2010). Among these characteristics, job autonomy and opportunities to participate in decision-making processes have attracted considerable attention in the literature as two of the most influential drivers in improving levels of organizational commitment (Brockner et al., 2004; De Guyper and De Witte, 2006; Mauno et al., 2007). Studies have also explored how various negative job demands can have a detrimental effect on organizational commitment. Low levels of organizational commitment have been linked to job insecurity (Sverke et al., 2002; Cheng and Chan, 2008), work-family conflict (Byron, 2005), increased workload (Bakker et al., 2010). Research has also explored the importance of organizational culture as an antecedent of organizational commitment, showing that the set of values and behavioral norms embodied in organizational culture, such as trust, fairness, and teamwork, have a positive effect on organizational commitment (Ostroff et al., 2005).

Compared to the extensive evidence on organization-based antecedents of organizational commitment, there is a paucity of evidence on the role of macroeconomic conditions in shaping employees' levels of commitment. The goal of this study, therefore, is to shed new light on whether macro-economic factors, such as unemployment rates, could influence the employees' level of organizational commitment, beyond the influence of individual characteristics or the influence of the immediate work environment. We argue that in areas of high unemployment, employees are likely to exhibit higher levels of commitment, because of the higher penalty of job loss, which strengthens the incentive for them to adopt a more disciplined attitude towards their employing organization. The study is undertaken for the case of Australia over the time span 2011-2014. The author argues that the structure of labor markets in Australia (i.e., strong unskilled workforce with great emphasis on part-time and causal jobs, especially for the youth workforce), along with the adverse economic growth conditions over the 2013-2014 period will provide solid evidence on whether sudden unemployment rates can impact loyalty commitments in the manufacturing sector of the country.

We can trace the notion of unemployment as an employee discipline device back to Shapiro and Stiglitz (1984), who theorized that, under certain conditions, unemployment becomes an effective tool for extracting maximum worker effort, without the need for costly workplace monitoring or supervision. The Shapiro-Stiglitz thesis on the role of unemployment as an important driver behind employee attitudes and workplace behaviors is particularly relevant in the context of employee commitment. Its non-coercive nature, as a psychological state that allows employees to feel loyal to their organization, precludes the use of direct monitoring as a means of improving organizational commitment. Alternatively, higher levels of organizational commitment in areas of high unemployment could be explained by a sense of gratitude that employees feel towards their organization for having 


\section{APERGIS Unemployment and Organizational Commitment}

offered them a sought after opportunity for gainful employment. In such a social exchange type of relational setting, it is also plausible that the external threat of high unemployment, which could potentially threaten the organization's own existence, might actually galvanize employees to becoming more loyal towards their organization. Yet, higher aggregate unemployment during an economic downturn could heighten feelings of job insecurity among employees, with a detrimental effect on their level of commitment to the organization. Admittedly, evidence suggests that employees who experienced the layoffs of fellow employees, but themselves survived a layoff, had their perceptions about their organization and their levels of commitment negatively affected (Brockner et al., 2004). In this study, we test whether unemployment has a positive effect on organizational commitment using data directly from the HILDA Survey.

\section{Theoretical Background and Hypotheses}

Meyer and Allen (1991) have proposed a conceptualization of organizational commitment based on three main dimensions: (1) continuance commitment, associated with the costs of leaving the organization; (2) normative commitment, when employees feel an obligation to stay with the organization; and (3) affective commitment, focusing on employees' emotional attachment to and identification with the organization. All three dimensions encompass a notion of commitment as a psychological state characterizing employees' relationship with the organization and influencing their intentions to leave or to remain (Meyer et al., 1993; Powell and Meyer, 2004). Admittedly, this conceptualization of commitment as merely a psychological state has been debated in the literature, with many researchers arguing that organizational commitment is more of an array of workplace attitudes and it is better defined by a set of observable workplace behaviors (Klein et al., 2012). Nevertheless, the above, three-dimensional conceptualization still provides a useful framework for exploring how aggregate unemployment influences each of three dimensions of organizational commitment.

Employees with a strong sense of continuance commitment are aware of the costs associated with leaving their organization. Exit costs include the loss of seniority benefits, which employees have accumulated over their tenure with the current employer, the potential loss of health insurance coverage due to pre-existing conditions, as well as other direct and indirect transaction costs associated with changing employers. Such costs are usually nonnegligible, even when the decision to change employers is voluntary. However, the financial and psychic costs associated with involuntary job loss, because of layoffs or dismissals, are generally higher than the costs of voluntary job separations. Most often, unemployment is associated with a drop in income, with a detrimental effect on living standards, but perhaps more importantly, unemployment has a salient negative impact on individuals' psychological well-being, which is all but transitory (Lucas et al., 2004). Indeed, the damaging impact of 
unemployment on individuals' self-esteem, emotional well-being, and physical health has been well documented (McKee et al., 2005).

A question that has attracted less attention in the literature is how others' unemployment affects the employed. Does an increase in the unemployment rate make the employed feel better because they have a secured anyway? Does higher unemployment increase the probability of job loss and feelings of job insecurity among employees? Recent studies in the subjective well-being literature offer some answers to these questions by confirming the existence of a strong link between job insecurity and life satisfaction (Clark et al., 2010). Research has also identified a strong link between job insecurity and employees' workplace attitudes, behaviors and commitment. Studies have found, for example, that higher aggregate unemployment creates feelings of job insecurity that have a direct effect on employees' organizational commitment (Dekker and Schaufeli, 1995; Sverke et al., 2002; Cheng and Chan, 2008). In a similar vein, Brockner et al. (2004) find that layoffs have a negative impact on organizational commitment and job performance of employees in the organization who are not affected directly by the layoffs, although this effect is moderated by the level of perceived control. Haysknecht et al. (2008) provide empirical evidence supporting the moderating effect of local unemployment in the relationship between unit-level satisfaction, commitment, and absenteeism. In an earlier study, Markham and McKee (1991) document that high unemployment rates inevitably result in employees having fewer opportunities outside their current employer, which compel them to reduce absenteeism. In fact, the idea of linking the cost of job loss to employee effort, commitment, and workplace behaviors could be traced back to the Shapiro and Stiglitz (1984) model of unemployment as a worker discipline device.

Underpinning the Shapiro-Stiglitz model is a utility maximization framework, which introduces a macro perspective into the individual, micro-level employee behavior. The model states that during periods of low unemployment rates, firms are raising wages, so that workers would have more to lose when they are caught shirking. Higher wages increase labor costs and they are thus detrimental to employment. In contrast, when unemployment rises there is less need for firms to pay higher wages to discourage employee shirking. In this sense, unemployment operates as a discipline device for employees not to shirk, eliminating the need for employers to offer higher wages or to introduce costly supervision and monitoring processes.

Although the Shapiro-Stiglitz model explains primarily why unemployment occurs in the first place, it also describes the behavior of rational workers who choose employment over unemployment by simply comparing the value of employment to the value of unemployment. How much the current employment is worth is determined by current earnings and by how long it is going to last, which depends on the probability of a worker losing her job and entering unemployment. When aggregate unemployment is low, or there is no unemployment, workers who lose their jobs are rehired instantaneously. In this case, the cost or penalty of job 


\section{APERGIS Unemployment and Organizational Commitment}

loss for 'shirkers' is not severe and therefore the only way for the firm to ensure high levels of productivity is to monitor workers with costly supervisory processes and managerial structures or to pay them above market wages. In contrast, higher unemployment introduces a penalty for workers who are not exerting maximum effort, as it makes it more difficult for them to return to employment after redundancy. This increases the value of employment with the current employer compared to the value of unemployment. Moreover, a lower probability of re-employment increases the duration of unemployment and the associated monetary costs, thus reducing further the value of the unemployment state. In this sense, as employees realize the potentially sizeable cost of job loss during periods of high unemployment, they have an incentive to maintain and cherish their current employment and to remain loyal and committed to their organization.

By emphasizing the potentially high cost of unemployment, the Shapiro-Stiglitz model offers an insightful framework for explaining how employees' continuance commitment increases when aggregate unemployment is high. Nevertheless, while the model explains why in times of heavy local unemployment, employees work harder to keep their jobs, it does not explain whether employees will do so in a state of fear over losing their jobs or because they feel emotionally connected with or they have a sense of obligation towards their organization (i.e., affective or normative commitment respectively). Nevertheless, these are plausible scenarios, as employees could perceive sluggish economic growth and rising unemployment as a threat to the organization that they work for, and not solely as a threat to their own jobs. In this case, normative commitment levels will increase as employees feel an obligation to exert more effort, which in turn will help their organization to survive through a period of challenging economic conditions.

From the above discussion, we derive the main testable hypothesis of the study:

\section{Hypothesis 1: In high-unemployment regions, employees report higher scores of organizational commitment than employees in low- unemployment areas.}

The effect of unemployment on employee loyalty differs across industries and types of organizations. Studies have identified significant differences in employee loyalty across the public and private sectors (Zeffane, 1994) and why unemployment affects public and private sector employees differently (Luechinger et al., 2010). They highlight differences between public and private sector employees in terms of their prosocial and public service motivation, i.e. prosocially-motivated employees self-select themselves into public service jobs (Georgellis et al., 2011). When confronted with the threat of unemployment, employees in the public sector adopt a more prosocial stance and become more loyal to their organization. Therefore, we hypothesize that: 
Review of Economic Analysis 8 (2016) 135-152

\section{Hypothesis 2: The effect of unemployment on employee loyalty differs across different types of organizations and industrial sectors.}

\section{Methodology}

The estimation is carried out through a fixed effect methodological approach. The panel equation is formed by considering both time and individual effects, except in the case where the analysis occurs explicitly for years 2011, 2012, 2013 and 2014. In this model, the intercept parameter is different for each individual and for each time period (where appropriate). The fixed effects model aims at controlling the effect of omitted variables that vary between individuals and remain constant over time. To this end, it is assumed that the intercept varies from individual to individual, but is constant over time, whereas the response parameters (i.e., the estimated coefficients) are constant for all subjects and across all time periods. However, to avoid any potential inefficiency effects associated with the estimations in the generic model, we make use of a dynamic version of fixed effects estimations, the 'pooled mean group' (PMG) estimators recommended by Pesaran et al. (1999). This estimator yields not only consistent, but also considerably more efficient estimates that the static fixedeffect methodological approach when the slope homogeneity restriction holds. In addition, the PMG estimator has two attractive features: i) it allows testing the above restriction via standard Hausman-type tests, and ii) it allows both the dynamic specification and error variances to differ across individuals, which constitutes a clear benefit since those variances may be quite different, reflecting disparities in the way individuals behave in labour markets. Finally, a clear benefit of this approach is that it yields consistent estimates of the long-run vector no matter whether the variables involved are I(1) or I(0).

\section{Data}

We use linked employer-employee data from the 2011 through the 2014 HILDA database, which surveys Australian establishments, covering workplaces with at least five employees. The sample is drawn from 427 establishments. It includes 4,695 employees interviewed in 2011, 4,873 employees in 2012, 5,085 employees in 2013, and 5,258 employees in 2014. Respondents are asked whether they agree with the following statements about working life: "I feel loyal to my organization". The responses are coded so that 5 = 'Strongly agree', $4=$ 'Agree', 3 = 'Neither agree nor disagree', 2 = 'Disagree', 1 = 'Strongly disagree'.

Due to the matched employer-employee nature of the data, they allow us to control for both employee- and establishment-level characteristics, when assessing the impact of unemployment on organizational commitment. As unemployment rates in 2014, were generally higher than in the previous waves, we also perform separate analyses for each wave to see whether unemployment matters more for employee commitment when it is more severe. In order to explore whether there are any sector differences in the way unemployment 


\section{APERGIS Unemployment and Organizational Commitment}

affects organizational commitment, we further disaggregate our analysis by type of establishment. Unemployment is measured using the Australian Bureau of Statistics unemployment for the seven Australian States. In 2013 and 2014, unemployment rates increased across all States and differences across regions became more salient than in the previous years. Finally, it is worth pointing out that unemployment data for 2010 were also obtained on the following grounds (and I thank a referee for mentioning this): given that the survey captures the commitment of the employees at a particular point of time, if commitment is to be affected by the unemployment rate, then it is also affected by the latest announced level of unemployment (at least). Based on the fact that annual data are used, it is the unemployment of the previous yearthat does belong to the available information set of the individuals interviewed, since statistical authorities announce the unemployment rates at the beginning of the next year. As a result, the analysis makes use of the unemployment rate of the latest announced unemployment rate, prior to the time that the survey took place. In other words, our modeling approach is employing the one-lag unemployment rate in the regression analysis.

Information from HILDA controls for job design, family friendly policies, high involvement management practices, and the size of the organization. The view that job design drives employee's loyalty is well established and is measured as a scale based on a latent trait model of three dimensions of the jobs of the largest occupation in the workplace (range 1-3): variety in the work, discretion over how the work is done, and control over pace at which the work is carried out. Higher scores indicate a more enriched job design, with a positive effect on employee loyalty. The positive influence of family friendly policies on loyalty is a latent score based on responses to questions about whether non-managerial employees are entitled to maternity leave, emergency care leave, work at home, term-time only contracts, jobsharing, workplace nursery, childcare subsidies, financial help to care for elderly relatives, and elder care leave (range 1-4). Higher values indicate more family friendly workplaces. High involvement management practices are measured by a latent trait model fitted to a set of indicators of the availability of the following nine flexible work and high involvement skills acquisition practices (Wood and de Menezes, 2008): quality circles, functional flexibility, team working, suggestion scheme, induction, interpersonal skills training, team briefing, information disclosure, and appraisal. In smaller establishments, interpersonal comparisons intensify and levels of loyalty are inextricably linked to the fairness about their relative status in comparison to that of their peers (range 1-9). Smaller firms display relational style management practices, less investment in workplace training, less collective voice through labor unions, and fewer opportunities for skills enhancement and career progression, increasing the vulnerability to the threat of unemployment.

Other controls used include job tenure ( 0 for no, 1 for yes), supervisory responsibility ( 0 for no, 1 for yes), the number of children, gender ( 1 for males, 0 for females) and age. 
Employee loyalty varies with job tenure and typically follows a U-shape relationship, consistent with the Honeymoon Effect hypothesis. Employees with supervisory responsibilities exhibit higher levels of loyalty, exemplifying differences in job content, autonomy, task variety, and perceived organizational support. The presence of children increases work-life balance concerns among working parents. Older workers are more loyal to their organizations. Most job changes occur during the early stages of an individual's career, implying that young workers are likely to pursue employment opportunities outside their current employer, while during periods of high unemployment, the penalty of job loss is higher for the young because of the lack of sufficient experience. Table 1 reports a summary of descriptive statics that provide a generic picture of the data sample used to explore the hypotheses under study. The Jarque-Bera statistic test suggests that the null hypothesis of normality is rejected in the cases of weekly pay, number of employees, high involvement management practices and unemployment.

Table 1: Descriptive Statistics

\begin{tabular}{|l|l|l|l|l|l|}
\hline Variables & Mean & S.D. & Min & Max & $\begin{array}{l}\text { Jarque- } \\
\text { Bera }\end{array}$ \\
\hline Loyalty & 3.4 & 1.93 & 0.8 & 4.8 & 1.29 \\
Age & 41.4 & 3.99 & 30 & 61 & 1.14 \\
Gender & 0.6 & 0.24 & 0 & 1 & 1.85 \\
No. of children & 2.2 & 0.85 & 0 & 4.3 & 2.38 \\
Job tenure & 0.6 & 0.37 & 0 & 1 & 0.5 \\
Supervisory & & & & & \\
Responsibility & 0.4 & 0.22 & 0 & 1 & 0.5 \\
Weekly pay & $\mathrm{A} \$ 544.2$ & 31.28 & 294.3 & 773.8 & 89.15 \\
No. of employees & 36.8 & 21.94 & 8 & 83 & 125.48 \\
High involvement & & & & & \\
management practices & 4.8 & 2.83 & 1 & 9 & 14.32 \\
Family friendly & & & & & \\
policies & 2.9 & 1.16 & 1 & 4 & 1.03 \\
Job design & 1.8 & 0.75 & 1 & 3 & 0.64 \\
Unemployment & 4.6 & 2.17 & 3.2 & 5.5 & 19.73 \\
\hline
\end{tabular}

S.D. = standard deviation, Jarque-Bera is the test for normality. 


\section{APERGIS Unemployment and Organizational Commitment}

\section{Empirical Analysis}

Because of the ordinal nature of the dependent variable, we estimate ordered probit regressions, with employees' loyalty being determined by a transformation of the various antecedents of loyalty into a cardinal latent index:

$$
(C)_{i}^{*}=\beta^{\prime} z_{i}+e_{i}
$$

where $\mathrm{c}$ indicates commitment/loyalty, $\mathbf{Z}_{\mathbf{i}}$ is a matrix of independent variables, $\beta$ is a vector of parameters to be estimated and $e_{i}$ is the error term assuming the usual properties. The matrix $\mathbf{Z}$ includes the following control variables: age rankings, gender, the number of children, job tenure, a measure of supervisory responsibility, weekly pay, the number of employees, high involvement in management practices, family friendly policies, job design and unemployment. The cardinal index of loyalty is then mapped into the observed $(C)_{i}$ :

$$
(C)_{i}=\left\{\begin{array}{ccc}
0 & \text { if } & -\infty \leq(C)_{i}^{*} \leq \mu_{1} \\
1 & \text { if } & \mu_{1}<(C)_{i}^{*} \leq \mu_{2} \\
& \vdots \\
4 & \text { if } \quad \mu_{4}<(C)_{i}^{*} \leq \infty
\end{array}\right.
$$

with $\mu_{i}$ representing the thresholds.

Table 2 presents that male employees are less likely to report high levels of loyalty than female employees, with the estimates remaining relatively constant over the period 20112014. Employee loyalty increases with age throughout the period under study. The highest levels of loyalty are reported by older workers in the over 60-age bracket. Employees in the 20-29-age bracket are less loyal.

The job tenure coefficients suggest a declining pattern of employee loyalty after the second year of tenure and till the fifth year of tenure across all years under study. For years 2011 and 2012 this pattern remains consistently the same for both the 5 to 10 years and 10 years or more time brackets. By contrast, for years 2013 and 2014 (the years characterized by higher unemployment levels) the loyalty increases for the tenures described by the 5 to 10 tears and 10 years or more time brackets, indicating that in stressful working times higher tenure levels remain (not) surprisingly loyal to their working place. Employees with supervisory responsibilities report high levels of loyalty throughout the years under 
Review of Economic Analysis 8 (2016) 135-152

Table 2: Unemployment and Employee Loyalty

\begin{tabular}{|c|c|c|c|c|}
\hline & Loyal2011 & Loyal2012 & Loyal 2013 & Loyal2014 \\
\hline Male & $-0.211 * *$ & $-0.218 * *$ & $-0.215^{* *}$ & $-0.213 * *$ \\
\hline \multicolumn{5}{|l|}{ Age } \\
\hline $20-21$ & -0.042 & -0.048 & $-0.066^{* *}$ & $-0.090 * *$ \\
\hline $22-29$ & $-0.121 * *$ & $-0.130 * *$ & $-0.152 * *$ & $-0.164 * *$ \\
\hline $30-39$ & 0.011 & 0.016 & 0.015 & 0.018 \\
\hline $40-49$ & 0.034 & 0.041 & 0.040 & 0.042 \\
\hline $50-59$ & 0.085 & $0.102 *$ & $0.138^{* *}$ & $0.173 * *$ \\
\hline $60-64$ & $0.252 * *$ & $0.268 * *$ & $0.285^{* *}$ & $0.303 * *$ \\
\hline 65 and above & $0.496^{* *}$ & $0.509 * *$ & $0.530 * *$ & $0.561 * *$ \\
\hline Number of children & -0.006 & -0.010 & -0.012 & -0.014 \\
\hline \multicolumn{5}{|l|}{ Job Tenure } \\
\hline 2 to less than 5 years & $-0.095 * *$ & $-0.115^{* *}$ & $-0.140 * *$ & $-0.166^{* *}$ \\
\hline 5 to less than 10 years & $-0.131 * *$ & $-0.139 * *$ & $0.160 * *$ & $0.174 * *$ \\
\hline 10 years or more & $-0.182 * *$ & $-0.189 * *$ & $0.212 * *$ & $0.230^{* *}$ \\
\hline Supervisory responsibility & $0.348 * *$ & $0.367 * *$ & $0.392 * *$ & $0.421^{* *}$ \\
\hline Weekly Pay & 0.000 & 0.000 & 0.000 & 0.000 \\
\hline \multicolumn{5}{|l|}{ Establishment level information } \\
\hline Number of employees & -0.010 & -0.013 & -0.011 & -0.014 \\
\hline High involvement management & $-0.050 * *$ & $-0.066^{* *}$ & $0.072 * *$ & $0.081 * *$ \\
\hline Family friendly policies & $-0.046^{* *}$ & $-0.058^{* *}$ & $-0.092 * *$ & $-0.109^{* *}$ \\
\hline Job design & $0.031 * *$ & $0.039 * *$ & $0.062 * *$ & $0.089 * *$ \\
\hline Unemployment rate(-1) & $0.022 * *$ & $0.024 * *$ & $0.061 * *$ & $0.084 * *$ \\
\hline CD test & {$[0.00]$} & {$[0.00]$} & {$[0.00]$} & {$[0.00]$} \\
\hline$R$-squared adjusted & 0.69 & 0.73 & 0.71 & 0.75 \\
\hline Log Likelihood & -1509.83 & -1482.64 & -1569.06 & -1593.29 \\
\hline Hausman test & [0.41] & {$[0.45]$} & [0.39] & [0.49] \\
\hline
\end{tabular}

Notes: $* p<.05 ; * * p<.01$. Figures in brackets denote $\mathrm{p}$-values.

investigation, with the coefficients receiving their higher value in years 2013 and 2014. Children and weekly pay do not seem to exert any significant impact on employee loyalty.

High involvement management practices have a negative influence on employee loyalty in 2011 and 2012, while the impact turns out to be positive over the 2013 and 2014 years. Employees in organizations with a greater availability of family-friendly policies report lower loyalty scores across all years (Georgellis et al., 2011), while employees in organizations with 


\section{APERGIS Unemployment and Organizational Commitment}

enriched job designs report higher scores for loyalty, again across all four years under examination. Finally, unemployment rates exert a positive effect on loyalty across all years, with the strongest impact occurring in the years 2013 and 2014 (0.061 and 0.084, respectively) that illustrate the years with increased unemployment rates across the Australian labor market. The findings in unemployment support Hypothesis 1. In States with high unemployment rates, employees report higher scores of loyalty. This confirms the role of unemployment as a potential mechanism influencing feelings of job insecurity and it is consistent with the Shapiro-Stiglitz view that unemployment operates as an employee discipline device that reduces the need for expensive monitoring. Finally, diagnostic tests indicate that the residuals in these models are cross-sectionally dependent, which justifies the employment of the PMG estimation approach, while the Hausman test indicates, in all cases, that the restriction of homogeneity cannot be rejected at the $1 \%$ significance level. Hence, once again the PMG estimation is appropriate to explore unemployment commitments.

Tables 3 to 6 report results separately by type of business and sector. The differential effects of weekly pay and the organizational-level variables are notable. The negative effect of high involvement management practices on employee loyalty in the public sector, local/central government and non-trading public companies is also notable. The findings suggest that while unemployment exerts a positive effect on employee loyalty only for those working in public and in private limited companies and in years 2011 and 2012, the impact turns to gain significance across all sectors in years 2013 and 2014. These results over the years 2011 and 2012 offer support to Hypothesis 2 and are consistent with arguments in the literature explaining why unemployment affects public and private sector employees differently (Luechinger et al., 2010).

By contrast, over the years 2013 and 2014 where unemployment figures revealed a worst employment scenario, the arguments set by Hypothesis 2 are no longer valid. At the same time, weekly pay over the years 2013 and 2014 turn out to be statistically insignificant across all types of organizations, illustrating that in stressful times employees disregard weekly pay as a key driver for their loyalty to their employment environment. Finally, diagnostic tests indicate again that the residuals in these models are cross-sectionally dependent, while the Hausman test indicates again that in all cases the restriction of homogeneity cannot be rejected at the $1 \%$ significance level. Overall, the results document that during stressful times, a number of factors that could impact employees' loyalty seem to have been deactivated due to higher uncertainty conditions in the economy in general, and in the labor markets in particular. 
Table 3: Unemployment and Employee Loyalty (Type of Business)-2011

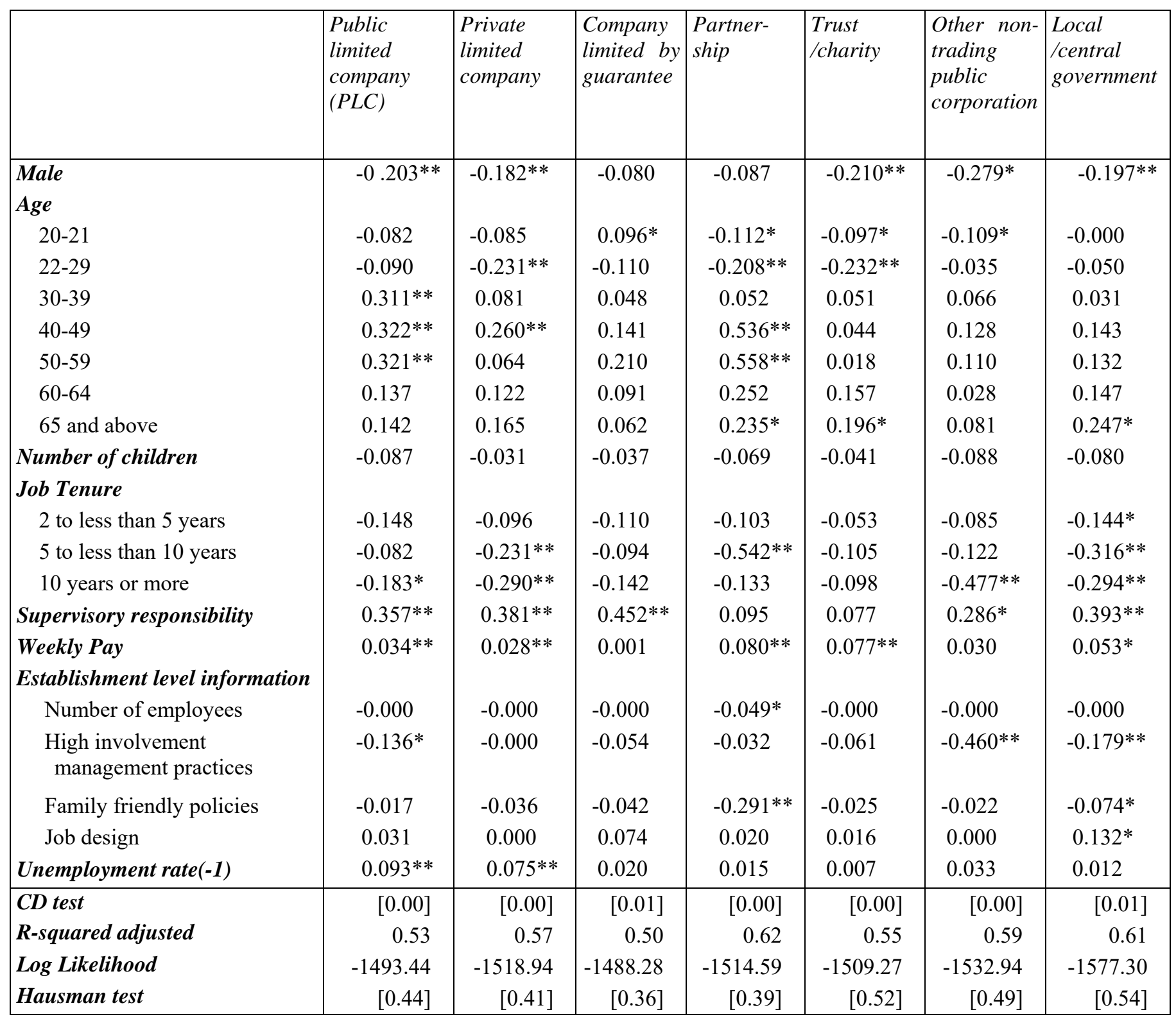

Notes: Similar to Table 1. 
APERGIS Unemployment and Organizational Commitment

Table 4: Unemployment and Employee Loyalty (Type of Business)-2012

\begin{tabular}{|c|c|c|c|c|c|c|c|}
\hline & $\begin{array}{l}\text { Public } \\
\text { limited } \\
\text { company } \\
(P L C)\end{array}$ & \begin{tabular}{|l|} 
Private \\
limited \\
company
\end{tabular} & $\begin{array}{l}\text { Company } \\
\text { limited by } \\
\text { guarantee }\end{array}$ & $\begin{array}{l}\text { Partner- } \\
\text { ship }\end{array}$ & \begin{tabular}{|l|} 
Trust \\
/charity
\end{tabular} & $\begin{array}{l}\text { Other non- } \\
\text { trading } \\
\text { public } \\
\text { corporatio } \\
n\end{array}$ & \begin{tabular}{|l|} 
Local \\
/central \\
government
\end{tabular} \\
\hline Male & $-0.191 * *$ & $-0.162 * *$ & -0.055 & -0.075 & $-0.198 * *$ & $-0.254^{*}$ & $-0.181 * *$ \\
\hline \multicolumn{8}{|l|}{ Age } \\
\hline $20-21$ & -0.073 & -0.075 & $0.090 *$ & $-0.102 *$ & $-0.087^{*}$ & $-0.099^{*}$ & -0.000 \\
\hline $22-29$ & -0.074 & $-0.207 * *$ & -0.089 & $-0.195 * *$ & $-0.214 * *$ & -0.024 & -0.040 \\
\hline $30-39$ & $0.290 * *$ & 0.053 & 0.037 & 0.042 & 0.045 & 0.051 & 0.024 \\
\hline $40-49$ & $0.293^{* *}$ & $0.241 * *$ & 0.120 & $0.511^{* *}$ & 0.033 & 0.110 & 0.119 \\
\hline $50-59$ & $0.306^{* *}$ & 0.050 & 0.183 & $0.528 * *$ & 0.006 & 0.081 & 0.117 \\
\hline $60-64$ & 0.122 & 0.101 & 0.073 & 0.220 & 0.124 & 0.012 & 0.121 \\
\hline 65 and above & 0.118 & 0.146 & 0.045 & $0.213^{*}$ & $0.180^{*}$ & 0.061 & $0.225^{*}$ \\
\hline Number of children & -0.062 & -0.020 & -0.022 & -0.041 & -0.020 & -0.062 & -0.055 \\
\hline \multicolumn{8}{|l|}{ Job Tenure } \\
\hline 2 to less than 5 years & -0.132 & -0.081 & -0.090 & -0.082 & -0.030 & -0.062 & $-0.119 *$ \\
\hline 5 to less than 10 years & -0.072 & $-0.208 * *$ & -0.084 & $-0.518 * *$ & -0.091 & -0.098 & $-0.301 * *$ \\
\hline 10 years or more & $-0.172 *$ & $-0.263 * *$ & -0.111 & -0.102 & -0.085 & $-0.447 * *$ & $-0.264 * *$ \\
\hline Supervisory responsibility & $0.334 * *$ & $0.350 * *$ & $0.424 * *$ & 0.082 & 0.060 & $0.254 *$ & $0.375^{* *}$ \\
\hline Weekly Pay & $0.043 * *$ & $0.036^{* *}$ & 0.000 & $0.093 * *$ & $0.087^{* *}$ & $0.050^{* *}$ & $0.069 * *$ \\
\hline \multicolumn{8}{|l|}{ Establishment level } \\
\hline Number of employees & -0.000 & -0.000 & -0.000 & -0.031 & -0.000 & -0.000 & -0.000 \\
\hline High involvement & $-0.125^{*}$ & -0.000 & -0.042 & -0.026 & -0.054 & $-0.434 * *$ & $-0.165 * *$ \\
\hline Family friendly policies & -0.011 & -0.023 & -0.035 & $-0.254 * *$ & -0.020 & -0.017 & $-0.067^{*}$ \\
\hline Job design & 0.020 & 0.000 & 0.061 & 0.006 & 0.007 & 0.000 & $0.117^{*}$ \\
\hline Unemployment rate(-1) & $0.07 * *$ & $0.056^{* *}$ & 0.007 & 0.010 & 0.000 & 0.012 & 0.000 \\
\hline CD test & {$[0.00]$} & {$[0.00]$} & {$[0.00]$} & {$[0.00]$} & {$[0.00]$} & {$[0.00]$} & {$[0.00]$} \\
\hline$R$-squared adjusted & 0.57 & 0.55 & 0.58 & 0.51 & 0.56 & 0.51 & 0.59 \\
\hline Log Likelihood & -1439.73 & -1472.18 & -1455.62 & -1469.61 & -1452.39 & -1549.64 & -1588.32 \\
\hline Hausman tets & {$[0.36]$} & [0.39] & {$[0.35]$} & [0.42] & [0.39] & {$[0.50]$} & {$[0.48]$} \\
\hline
\end{tabular}

Notes: Similar to Table 1. 
Review of Economic Analysis 8 (2016) 135-152

Table 5: Unemployment and Employee Loyalty (Type of Business)-2013

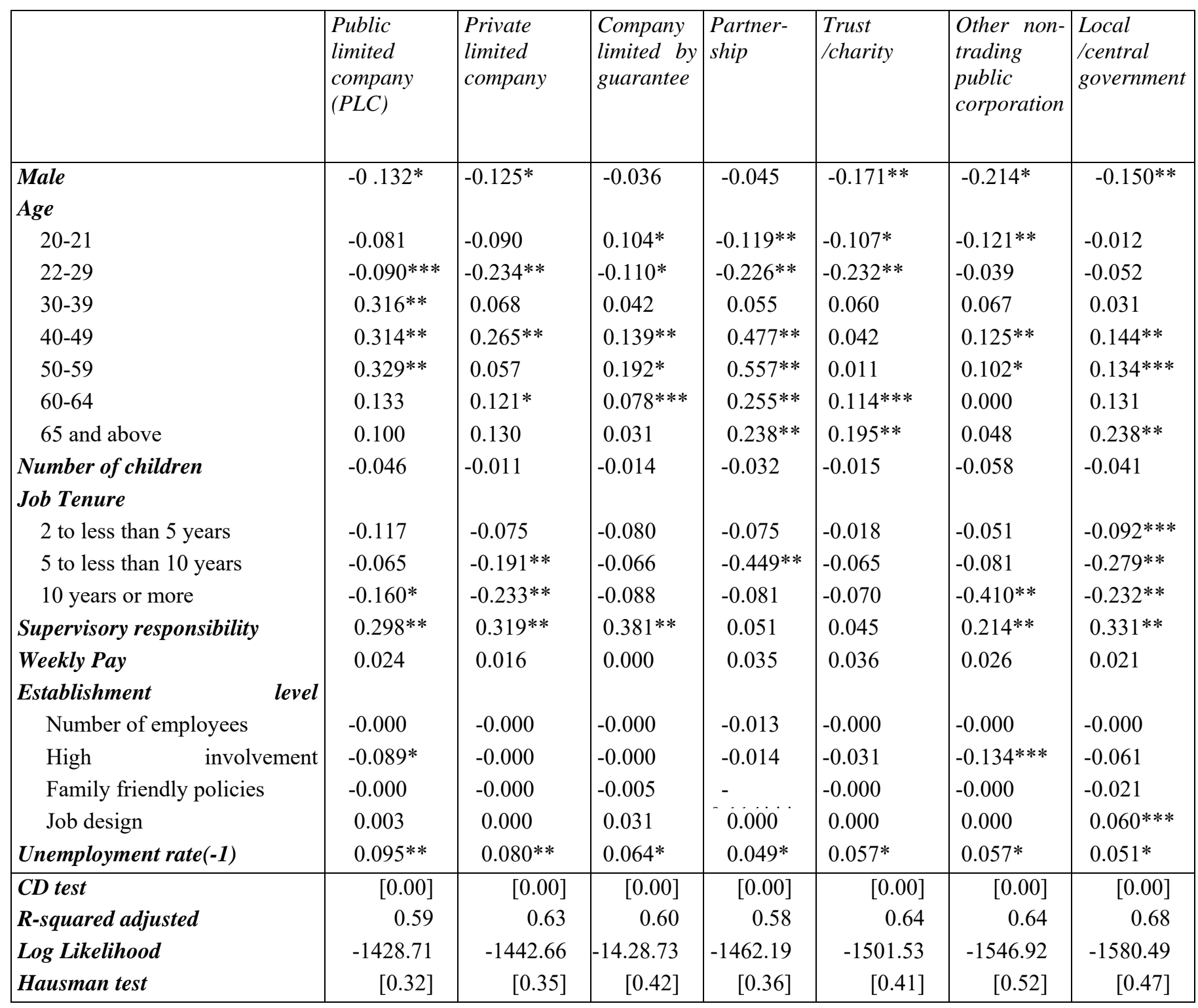

Notes: Similar to Table $1, * * * p<.10$ 
APERGIS Unemployment and Organizational Commitment

Table 6: Unemployment and Employee Loyalty (Type of Business)-2014

\begin{tabular}{|c|c|c|c|c|c|c|c|}
\hline & $\begin{array}{l}\text { Public } \\
\text { limited } \\
\text { company } \\
(P L C)\end{array}$ & $\begin{array}{l}\text { Private } \\
\text { limited } \\
\text { company }\end{array}$ & \begin{tabular}{|l|} 
Company \\
limited by \\
guarantee
\end{tabular} & $\begin{array}{r}\text { Partner- } \\
\text { ship }\end{array}$ & \begin{tabular}{|l|} 
Trust \\
/charity
\end{tabular} & \begin{tabular}{|l|} 
Other non- \\
trading \\
public \\
corporation
\end{tabular} & \begin{tabular}{|l} 
Local \\
/central \\
government
\end{tabular} \\
\hline Male & $-0.122 *$ & $-0.108^{*}$ & -0.024 & -0.031 & $-0.150 * *$ & $-0.153 * * *$ & - \\
\hline \multicolumn{8}{|l|}{ Age } \\
\hline $20-21$ & -0.055 & -0.070 & $0.082 * * *$ & $-0.103 *$ & $-0.087 * * *$ & $-0.109 *$ & -0.000 \\
\hline $22-29$ & $-0.069 * * *$ & $-0.183^{*}$ & $-0.091 * * *$ & $-0.182 * *$ & $-0.208 * *$ & -0.021 & -0.032 \\
\hline $30-39$ & $0.282 * *$ & 0.040 & 0.024 & 0.041 & 0.040 & 0.050 & 0.017 \\
\hline $40-49$ & $0.280^{* *}$ & $0.221 * *$ & $0.113^{*}$ & $0.417^{* *}$ & 0.022 & $0.101 *$ & $0.123 *$ \\
\hline $50-59$ & $0.299 * *$ & 0.030 & $0.150^{*}$ & $0.509 * *$ & 0.000 & $0.070 * * *$ & $0.098 * * *$ \\
\hline $60-64$ & 0.094 & 0.068 & 0.045 & $0.208^{* *}$ & 0.074 & 0.000 & 0.065 \\
\hline 65 and above & 0.077 & $0.096 * * *$ & 0.000 & $0.208 * *$ & $0.150 * *$ & 0.020 & $0.215^{* *}$ \\
\hline Number of children & -0.012 & -0.000 & -0.000 & -0.000 & -0.000 & -0.028 & -0.022 \\
\hline \multicolumn{8}{|l|}{ Job Tenure } \\
\hline 2 to less than 5 years & -0.074 & -0.052 & -0.044 & -0.057 & -0.000 & -0.030 & -0.053 \\
\hline 5 to less than 10 years & -0.020 & $-0.158 * *$ & -0.040 & $-0.398 * *$ & -0.028 & -0.051 & $-0.225 * *$ \\
\hline 10 years or more & $-0.104 * * *$ & $-0.189 * *$ & -0.044 & -0.048 & -0.031 & $-0.344 * *$ & $-0.188^{* *}$ \\
\hline Supervisory responsibility & $0.241 * *$ & $0.269 * *$ & $0.306^{* *}$ & 0.011 & 0.027 & $0.177 * *$ & $0.271 * *$ \\
\hline Weekly Pay & 0.002 & 0.000 & 0.000 & 0.008 & 0.014 & 0.007 & 0.001 \\
\hline \multicolumn{8}{|l|}{ Establishment level } \\
\hline Number of employees & -0.000 & -0.000 & -0.000 & -0.003 & -0.000 & -0.000 & -0.000 \\
\hline High involvement & -0.032 & -0.000 & -0.000 & -0.000 & -0.009 & -0.070 & -0.042 \\
\hline Family friendly policies & -0.000 & -0.000 & -0.000 & -0.071 & -0.000 & -0.000 & -0.000 \\
\hline Job design & 0.000 & 0.000 & 0.008 & 0.000 & 0.000 & 0.000 & 0.031 \\
\hline Unemployment rate-1) & $0.143^{* *}$ & $0.130^{*}$ & $0.125^{*}$ & $0.152 * *$ & $0.140^{*}$ & $0.155^{* *}$ & $0.151^{* *}$ \\
\hline CD test & {$[0.00]$} & {$[0.00]$} & {$[0.00]$} & {$[0.00]$} & {$[0.00]$} & {$[0.00]$} & {$[0.00]$} \\
\hline$R$-squared adjustd & 0.68 & 0.72 & 0.70 & 0.67 & 0.73 & 0.65 & 0.76 \\
\hline Log Likelihood & -1525.48 & -15.40 .85 & -1539.73 & -1552.18 & -1579.30 & -1620.41 & -1658.74 \\
\hline Hausman test & {$[0.46]$} & [0.49] & {$[0.44]$} & {$[0.42]$} & [0.49] & {$[0.53]$} & {$[0.58]$} \\
\hline
\end{tabular}

Notes: Similar to Table 1 


\section{Conclusion}

Unemployment has been sidelined in the employee loyalty literature. Existing work has relied mostly on psychological contract and social exchange based explanations. Through the Shapiro and Stiglitz theoretical framework, it was argued that higher unemployment increases the cost of job loss, which has a positive effect on employee loyalty. Unemployment heightens feelings of job insecurity and has a direct effect on how employees perceive their current employment state to be.

The empirical analysis investigated two primary hypotheses: i) whether high unemployment affects positively organizational commitment attitudes and ii) whether the effect of unemployment on such commitments differs across different types of organizations and industrial sectors. Through the employment of a large dataset of survey data from the Australian manufacturing sector, the findings documented that in relevance to the first hypothesis, regions characterized by higher unemployment rates have a stronger impact on loyalty commitments across employees, thus, providing solid supportive evidence to the first hypothesis tested. With respect to the second hypothesis, the results illustrated that unemployment retained its positive impact on employee loyalty, while the findings gain stronger power primarily for those working in public and in private limited companies and for the time span 2013-2014 in which Australian labor markets suffered from higher unemployment rates.

While many of the internal drivers of loyalty can be shaped by the organization, other factors, such as unemployment, are largely outside the control of the organization. Organizations should take a closer look at the reasons why individuals are loyal to them. Whilst some feel attached towards their organization, because of a supportive work environment, others may choose to be loyal because they fear the negative consequences of becoming unemployed.

\section{References}

Allen, N.J. and Meyer, J.P. (1996). Affective, Continuance, and Normative Commitment to the Organization: An Examination of Construct Validity, Journal of Vocational Behavior, 49, 252-276.

Bakker, A.B., van Veldhoven, M. and Xanthopoulou, D. (2010), Beyond the Demand-Control Model: Thriving on High Job Demands and Resources, Journal of Personnel Psychology, 9, 3-16.

Brockner, J., Spreitzer, G., Mishra, A., Hochwarter, W., Pepper, L. and Weinberg, J. (2004), Perceived Control as an Antidote to the Negative Effects of Layoffs on Survivors' Organizational Commitment and Job Performance, Administrative Science Quarterly, 49, 76-100. 


\section{APERGIS Unemployment and Organizational Commitment}

Byron, K. (2005), A Meta-Analytic Review of Work-Family Conflict and its Antecedents, Journal of Vocational Behavior, 67, 169-198.

Cheng, G.H. and Chan, D.K. (2008), Who Suffers More From Job Insecurity? A Meta Analytic Review, Applied Psychology, 57, 272-303.

Clark, A., Knabe, A. and Rätzel, S. (2010), Boon or Bane? Others' Unemployment, WellBeing and Job Insecurity, Labour Economics, 17, 52-61.

Dale, K. and Fox, M.L. (2008), Leadership Style and Organizational Commitment: Mediating Effect of Role Stress, Journal of Managerial Issues, 20, 109-130.

De Cuyper, N. and De Witte, H. (2006), Autonomy and Workload Among Temporary Workers: Their Effects on Job Satisfaction, Organizational Commitment, Life Satisfaction, and Self-Rated Performance, International Journal of Stress Management, 13, 441-459.

Dekker, S.W. and Schaufeli, W.B. (1995), The Effects of Job Insecurity on Psychological Health and Withdrawal: A Longitudinal Study, Australian Psychologist, 30, 57-63.

Demerouti, E., Bakker, A.B., Nachreiner, F. and Schaufeli, W.B. (2001), The Job DemandsResources Model of Burnout, Journal of Applied Psychology, 86, 499-512.

Fulmer, C.A. and Gelfand, M.J. (2012), At What Level (and in Whom) We Trust Across Multiple Organizational Levels, Journal of Management, 38, 1167-1230.

Georgellis, Y., Iossa, E. and Tabvuma, V. (2011), Crowding Out Intrinsic Motivation in the Public Sector, Journal of Public Administration Research and Theory, 21, 473-493.

Klein, H.J., Molloy, J.C. and Brinsfield, C.T. (2012), Reconceptualising Workplace Commitment to Redress a Stretched construct: Revisiting Assumptions and Removing Confounds, Academy of Management Review, 37, 130-151.

Kleine, C. and Weißenberger, B.E. (2014), Leadership Impact on Organizational Commitment: The Mediating Role of Management Control Systems Choice, Journal of Management Control, 24, 241-266.

Lucas, R.E., Clark, A.E., Georgellis, Y. and Diener, E. (2004), Unemployment Alters the Set Point for Life Satisfaction, Psychological Science, 15, 8-13.

Luechinger, S., Meier, S. and Stutzer, A. (2010), Why Does Unemployment Hurt the Employed? Evidence from the Life Satisfaction Gap Between the Public and the Private Sector, Journal of Human Resources, 45, 998-1045.

Mauno, S., Kinnunen, U. and Ruokolainen, M. (2007), Job Demands and Resources as Antecedents of Work Engagement: a Longitudinal Study, Journal of Vocational Behavior, 70, 149-171.

McKee-Ryan, F., Song, Z., Wanberg, C. R. and Kinicki, A.J. (2005), Psychological and Physical Well-Being During Unemployment: A Meta-Analytic Study, Journal of Applied Psychology, 90, 53-76. 
Meyer, J.P. and Allen, N.J. (1991), A Three-Component Conceptualization of Organizational Commitment, Human Resource Management Review, 1, 61-89.

Meyer, J.P., Allen, N.J. and Smith, C.A. (1993), Commitment to Organizations and Occupations: Extension and Test of a Three-Component Conceptualization, Journal of Applied Psychology, 78, 538-551.

Meyer, J.P., Stanley, D.J., Herscovitch, L. and Topolnytsky, L. (2002), Affective, Continuance, and Normative Commitment to the Organization: A Meta-Analysis of Antecedents, Correlates, and Consequences, Journal of Vocational Behavior, 61, 20-52.

Ostroff, C., Shin, Y. and\& Kinicki, A.J. (2005), Multiple Perspectives of Congruence: Relationships Between Value Congruence and Employee Attitudes, Journal of Organizational Behavior, 26, 591-623.

Pesaran, M.H., Shin, Y. and Smith, R. (1999), Pooled Estimation of Long-Run Relationships in Dynamic Heterogeneous Panels, Journal of the American Statistical Association, 94, 621-634.

Podsakoff, P.M., MacKenzie, S.B. and Bommer, W.H. (1996), Transformational Leader Behaviors and Substitutes for Leadership as Determinants of Employee Satisfaction, Commitment, Trust, and Organizational Citizenship Behaviors, Journal of Management, 22, 259-298.

Powell, D.M. and Meyer, J.P. (2004), Side-Bet Theory and the Three-Component Model of Organizational Commitment, Journal of Vocational Behavior, 65, 157-177.

Sverke, M., Hellgren, J. and Näswall, K. (2002), No Security: A Meta-Analysis and Review of Job Insecurity and its Consequences, Journal of Occupational Health Psychology, 7, 242-264.

Walumbwa, F.O. and Lawler, J.J. (2003), Building Effective Organizations: Transformational Leadership, Collectivist Orientation, Work-Related Attitudes and Withdrawal Behaviours in Three Emerging Economies, International Journal of Human Resource Management, 14, 1083-1101.

Wood, S. and de Menezes, L.M. (2008), Comparing Perspectives on High Involvement Management and Organizational Performance Across the British Economy, The International Journal of Human Resource Management, 19, 639-683.

Zeffane, R. (1994), Patterns of Organizational Commitment and Perceived Management Style: A Comparison of Public and Private Sector Employees, Human Relations, 47, $977-$ 1010. 